\title{
POŚTA
}

TELEKOMUNIKÁCIE A

ELEKTRONICKY OBCHOD

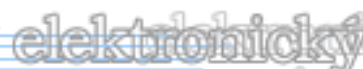

(n)

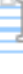

\section{VYUŽITIE AUTOMATOV NA BITCOINY NA POBOČKÁCH PÔŠT}

\author{
Iveta Kremeňová $^{1}$, Juraj Fabuš², Dominika Koncováa ${ }^{3}$
}

\begin{abstract}
Bitcoin, as a virtual currency, is one of the commonly available and used currencies. The aim of the paper is to analyze the use of ATMs for virtual currencies used at post offices. The article consists of an analysis of available ATMs for virtual currencies as well as a comparison of their possibilities. The paper presents a comparison of the three most important ATM manufacturers in the scope of their most used models.
\end{abstract}

Keywords: ATMs for virtual currency, Bitcoin, post office.

\section{Úvod}

S vývojom l'udstva sa vyvíjajú aj nové platobné možnosti. Od najstarších foriem peňazí cez plnohodnotné a neplnohodnotné peniaze sme sa dostali až $\mathrm{k}$ súčasným elektronickým peniazom. Bitcoin, patrí medzi najpopulárnejšie a najsilnejšie elektronické peniaze $\mathrm{v}$ súčasnosti. [1]

Konvergencia informačno-komunikačných technológií vytvára neustále nové príležitosti a digitalizáciu štátnych podnikov v elektronických službách. Tak je to aj v oblasti virtuálnej meny, ktorej história najskôr vel'mi nepriala a l’udia boli z jej budúcnosti skeptický. Postupom času sa virtuálna mena zaradzuje medzi bežne dostupné a používané platidlo. Tomuto trendu podliehajú aj mnohé podniky, a ponúkajú svojím zákazníkom možnost' nakupovat' a platit' $v$ tejto virtuálnej mene rôzne služby. [1], [2]

Poskytovanie poštových služieb na území Slovenskej republiky ponúka viacero podnikov, pričom Slovenská pošta, a.s., je popredný poskytovatel' distribučných, komunikačných a platobných služieb na trhu. [3], [4]

Bankomat (v angličtine - Automated Teller Machine - ATM) je samoobslužné zariadenie, určené na výdaj hotovosti. Platobná karta a k nej príslušný PIN kód slúžia ako identifikačný prostriedok, ktorý umožní výber peňažnej hotovosti. Bankomat vydáva len papierové peniaze. Prvý automat na peniaze bol nainštalovaný ešte v Československu. Zavedený do prevádzky bol 15. januára 1989 v Prahe na Václavskom námestí. Nainštalovala ho Česká sporitel’ňa priamo $\mathrm{v}$ budove banky, zo začiatku bol automat dostupný len zamestnancom. [5], [6]

Prvý automat na virtuálnu menu Bitcoin v Európe bol inštalovaný v Progress Bar-e 21.11.2013. Do prevádzky bol uvedený od 8.12.2013. Bankomat na virtuálnu menu Bitcoin funguje ako peňaženka. Konkrétnu bankovku v mene euro zamení podl'a aktuálneho kurzu burzy Mt.gox., na Bitcoiny. Tento automat vyrobila firma Lamassu. [6], [7]

\footnotetext{
${ }^{1}$ doc. Ing. Iveta Kremeňová, PhD., Žilinská univerzita v Žiline, Fakulta prevádzky a ekonomiky dopravy a spojov, e-mail: iveta.kremenova@fpedas.uniza.sk

${ }^{2}$ Ing. Juraj Fabuš, PhD., Žilinská univerzita v Žiline, Fakulta prevádzky a ekonomiky dopravy a spojov, e-mail: juraj.fabus@ fpedas.uniza.sk

${ }^{3}$ Ing. Dominika Koncová, Žilinská univerzita v Žiline, Fakulta prevádzky a ekonomiky dopravy a spojov, email: dominika.koncova@stud.uniza.sk
} 
Nová éra informačných technológií priniesla zároveň aj nové prvky výmenných prostriedkov. Virtuálna mena je neregulovatel'ná forma digitálnych peňazí, a môže sa použit' ako platobný peňažný prostriedok. Centrálna banka negarantuje stabilitu virtuálnej meny, teda nie je kontrolovaná a garantovaná centrálnou bankou. Virtuálne meny existujú len v elektronickom svete, $\mathrm{v}$ podobe sociálnych sieti a online počítačových hier. $\mathrm{V}$ súčasnosti sa používajú čoraz viac ako prostriedok platenia za služby a tovar u maloobchodníkov. Pri platbe nevznikajú žiadne alebo iba minimálne poplatky za transakciu. Bitcoin ako prvá mena nastavila podmienky bez centrálneho servera typu P2P, označovaná aj ako kryptomena. Bitcoin je decentralizovaná virtuálna mena. [8], [9]

\section{Bankomaty na poštách}

Analyzovanie bankomatov na poštách, s konkrétnym zameraním sa na bankomaty na virtuálne meny je ciel'om článku.

Výskum sa venuje problematike využívania bankomatov na virtuálne meny na poštách. Na porovnanie sme si vybrali Českú a Rakúsku poštu. Českú poštu sme si vybrali ako príklad krajiny, kde boli tieto bankomaty na virtuálne meny zavedené, no následne boli zrušené z pobočiek pošty. Rakúska pošta je zas príklad krajiny, kde tento systém funguje v niekol'ko tisíc poštových pobočiek a stále sa ich portfólio rozširuje.

Prvý bankomat nainštalovaný na virtuálnu menu v Českej republike sa nachádza v pražských Holešoviciach. V centre neziskovej organizácie Brmlab. [10]

Od 21.1.2015 bolo možné v pobočkách Českej pošty a terminálov Sazky nakupovat' virtuálnu menu Bitcoin. Prevádzkovala ju spoločnost' World BTC Business. Dovtedy sa virtuálna mena dala fyzicky zakúpit’ iba v samoobslužných zariadeniach vo väčších mestách.

Postup pri nákupe Bitcoinu začal na stránke easyconi.wbtcb.com, záujemca zvolil za akú sumu chce Bitcoin, zadal číslo svojej bitcoinovej peňaženky a následne mu prišlo potvrdenie o objednávke $\mathrm{s}$ identifikačným číslom platby. Na základe identifikačného čísla $\mathrm{v}$ pobočke ČP, s. p. prebehla úhrada a následne sa do elektronickej peňaženky klienta previedli zakúpene Bitcoiny. Limit bol od 500Kč do 25 000Kč. [11], [12]

Rakúsko je podl'a Coin ATM radar na piatom mieste s počtom $142 \mathrm{ks}$ nainštalovaných bankomatov na virtuálnu menu. Viac ako 1800 poštových pobočiek Rakúskej pošty ponúka predaj virtuálnej meny. Službu zabezpečujú prostredníctvom spoločnosti BitPanda. Spoločnost' BitPanda bola založená vo Viedni v roku 2014. Má viac ako 300000 používatel'ov a v pláne dosiahnut' čo najväčší objem transakcií (cca 200 miliónov $€$ ), aj vd’aka spolupráci s Rakúskou poštou. Platforma BitPanda (predtým Coinimal), je služba na nákup digitálnej meny, ktorá sa nachádza v Rakúsku a pôsobí na celom svete. Pomáha pri rýchlej, bezpečnej a lacnej kúpe niekol'kých digitálnych mien pomocou kreditných a debetných kariet alebo online bankovým prevodom. Je to tiež jedna z niekol'kých služieb, ktoré predávajú fyzicky splatené krypto-poukážky. [13], [14], [15], [16]

Najjednoduchší spôsob, ako si zakúpit’ virtuálnu menu je pomocou bankomatu (ATM). Existujú dva základné typy automatov One-Way (jednosmerný) a Two-Way (obojsmerných). One-Way automat ponúka iba možnost' vkladu. Two-Way automat ponúka vklad a výber.

Existuje 31 spoločností, ktoré vyrábajú automaty na virtuálne meny. My si predstavíme tie najznámejšie na trhu (podl’a webovej stránky coinatmradar.com). Ide o ATM GenesisCoin, General Bytes, Lamassu a Bitaccess. V tejto časti porovnáme najvýznamnejších 3 výrobcov bankomatov a ich najpoužívanejšie modely. GENESIS s počtom 937 nainštalovaných bankomatov, GENERAL BYTES s počtom 794 ks nainštalovaných bankomatov a LAMASSU s počtom 326 ks nainštalovaných bankomatov z celkového počtu 2844ks. [17]

Súčast'ou výskumu bol hlavne prieskum využívania bankomatov na poštách so zameraním na virtuálnu menu. Metódu výskumu sme si zvolili formou dotazníkov. 
Základným ciel’om dotazníkov bolo zistenie znalostí v oblasti digitálnych mien u zákazníkov (dotazník č. 1) a v poštových podnikoch (dotazník č. 2). Dotazníky boli vypracované na webovom portáli Google, pomocou aplikácie Formuláre Google. Dotazníky sme odoslali prostredníctvom sociálnej siete a emailom. V dotazníku č. 2 sme podniky oslovili telefonicky, e-mailom a dodatočne ho vyplnili $v$ ich mene.

Prácu sme si rozdelili na dve fázy. Prvá fáza je prípravná, kde sme stanovili výskumné otázky, ktoré budeme skúmat'. Druha fáza je realizačná, kde sme odpovedali na stanovené výskumné otázky. Pre výpočet vel'kosti vzorky bola stanovená 95\%-tná spol'ahlivost' odhadu, a maximálne rozpätie chýb $\pm 10 \%$. Podiel znaku 0,5 . Minimálna vel'kost' vzorky v prípade respondentov - zákazníkov Slovenskej pošty je 384 respondentov. Výskum obsahoval 12 výskumných predpokladov. Pre výpočet vzorky poštových podnikov, ktorých je 24 , bola stanovená 95\%-tná spol'ahlivost' odhadu, maximálne prípustné rozpätie chýb $\pm 5 \%$ a podiel znaku 0,5. Minimálna vel'kost' vzorky $\mathrm{v}$ tomto prípade je 19 respondentov. Výskum obsahoval 4 výskumné predpoklady.

\section{Výsledky prieskumu a porovnanie bankomatov na virtuálne meny}

Začiatkom roku 2021 bolo na Slovensku 9 obojsmerných (vklad aj výber) a 8 jednosmerných (iba vklad) automatov na virtuálnu menu. [18] Slovenská pošta a.s., zatial' neponúka a ani nevyužíva túto službu (bankomaty na virtuálne meny).

Slovenská republika je v počte nainštalovaných automatov na virtuálnu menu zatial' medzi poprednými miestami aj ked' počet bankomatov nie je vel'ký. Patrí medzi prvé krajiny, kde sa takýto bankomat na virtuálnu menu inštaloval. Konkrétne podl'a Coin ATM radar, je Slovenská republika na trinástom mieste s počtom $17 \mathrm{ks}$ nainštalovaných automatov na virtuálnu menu. Česká republika, je podl'a Coin ATM radar na šiestom mieste s počtom 40ks nainštalovaných bankomat na virtuálnu menu.

Nasleduje grafické zobrazenie aktuálnych informácií o bankomatoch nainštalovaných po celom svete. Obrázok 1 znázorňuje všetky inštalované bankomaty na Bitcoin ATMs, od konkrétneho výrobcu. [17]

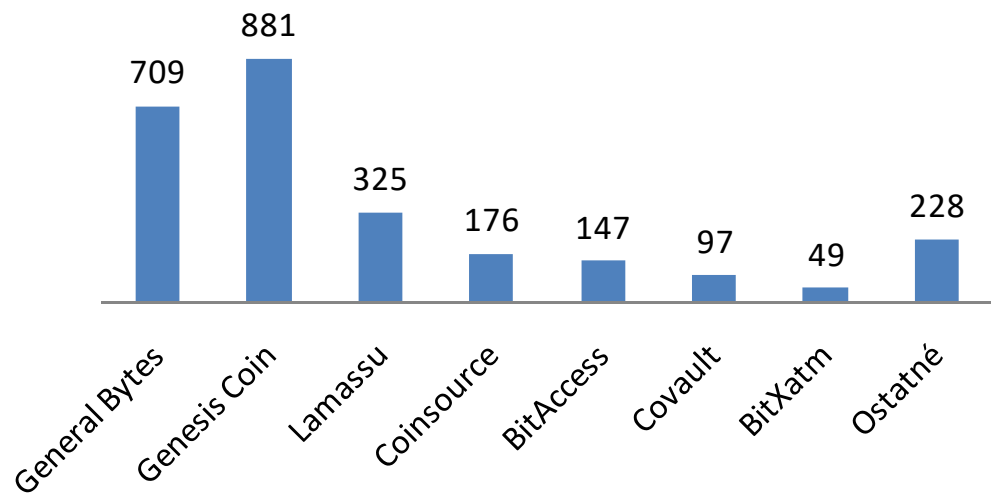

\section{Obrázok 1 Grafické znázornenie podielu ATM podl’a výrobcu (Vlastné spracovanie)}

Obrázok 2 zobrazuje kol'ko bankomatov Bitcoin, je nainštalovaných vo všetkých kontinentoch. (zvyšné 3 kontinenty nie sú zahrnuté $\mathrm{v}$ grafe, $\mathrm{z}$ dôvodu nezverejnených informácií o počte bankomatov na virtuálnu menu). [17] 


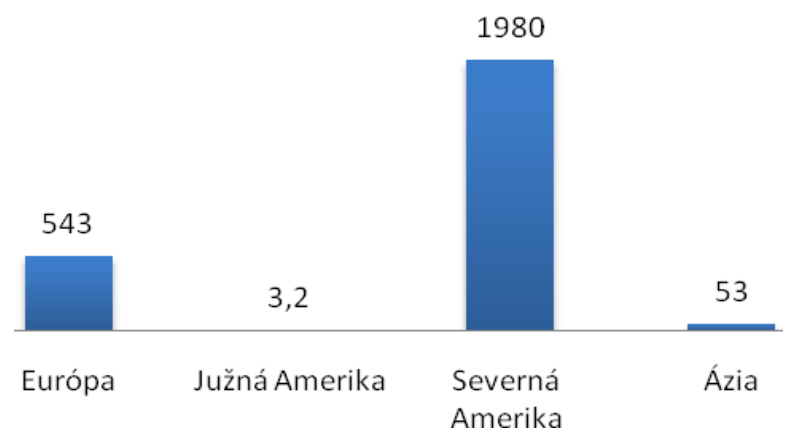

Obrázok 2 Grafické znázornenie podielu ATM podl'a kontinentu (Vlastné spracovanie)

Obrázok 3 zobrazuje, kol'ko je z celkového počtu nainštalovaných ATM, One-Way (jednosmerný) a Two-Way (obojsmerných) automatov. [17]

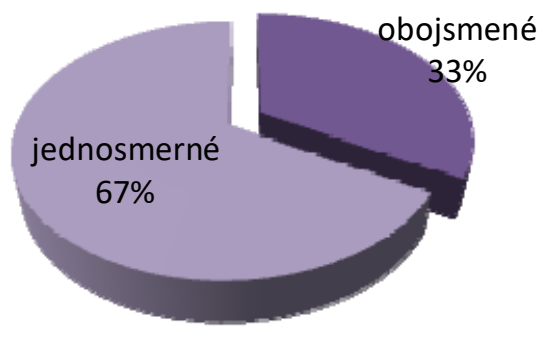

\section{Obrázok 3 Grafické znázornenie jednosmerného a obojsmerného ATM (Vlastné spracovanie)}

V tabul'ke 1 sú pre príklad porovnané tri najpoužívanejšie bankomaty na virtuálnu menu. Prvý stĺpec rozdel'uje bankomaty podl'a možnosti vkladu a výberu, v druhom riadku sú uvedené kapacity bankoviek bankomatu. V tret'om riadku sú porovnané základne prednosti bankomatov. Štvrtý riadok opisuje možnost' montáže samotného bankomatu. V poslednom riadku sú uvedené ceny bankomatov.

Tabul'ka 1 Porovnanie funkcií bankomatov na virtuálnu menu

\begin{tabular}{|c|c|c|}
\hline \multicolumn{3}{|c|}{ abul'ka 1 Porovnanie funkcií bankomatov na virtuálnu menu } \\
\hline GENESIS - GENESIS 1 & $\begin{array}{l}\text { GENERAL BYTES - } \\
\text { BATMTWO CLASSIC }\end{array}$ & $\begin{array}{ll}\text { LAMASSU - } & \text { DOURO } \\
+ \text { SANTO TIRSO } & \end{array}$ \\
\hline jednosmerný/obojsmerný & jednosmerný & jednosmerný/obojsmerný \\
\hline $\begin{array}{l}\text { Kapacita } 2200 \text { ks bankoviek a } \\
1700-6800 \text { výstup }\end{array}$ & $\begin{array}{l}\text { Kapacita } 600 \text { ks bankoviek } \\
\text { a } 2 \text { x500 ks výstup }\end{array}$ & $\begin{array}{l}\text { Kapacita } 600 \text { ks bankoviek } \\
\text { a 2x } 500 \text { ks výstup }\end{array}$ \\
\hline $\begin{array}{l}\text { Čítačka kariet EMV, validátor, } \\
\text { tepelná tlačiareň, fotoaparát, } \\
\text { čítačka čiarového kódu, } \\
\text { elektronická pokladnica, snímač } \\
\text { čiarových kódov }\end{array}$ & $\begin{array}{l}\text { Elektronická tlačiareň, } \\
\text { validátor, FHD dotykový } \\
\text { displej s Androidom, } \\
\text { elektronická pokladnica }\end{array}$ & $\begin{array}{l}\text { Čítačka QR, uzamykatel’ný } \\
\text { trezor, validátor, } \\
\text { podporované všetky meny, } \\
\text { databáza služieb tretích } \\
\text { strán }\end{array}$ \\
\hline Stojan súčast’ou & $\begin{array}{l}\text { Namontovaný môže byt' } \\
\text { na stene alebo pomocou } \\
\text { stojanu (dokupuje sa } \\
\text { samostatne) }\end{array}$ & $\begin{array}{l}\text { Namontovaný môže byt' na } \\
\text { stene alebo pomocou } \\
\text { stojanu (dokupuje sa } \\
\text { samostatne) }\end{array}$ \\
\hline
\end{tabular}




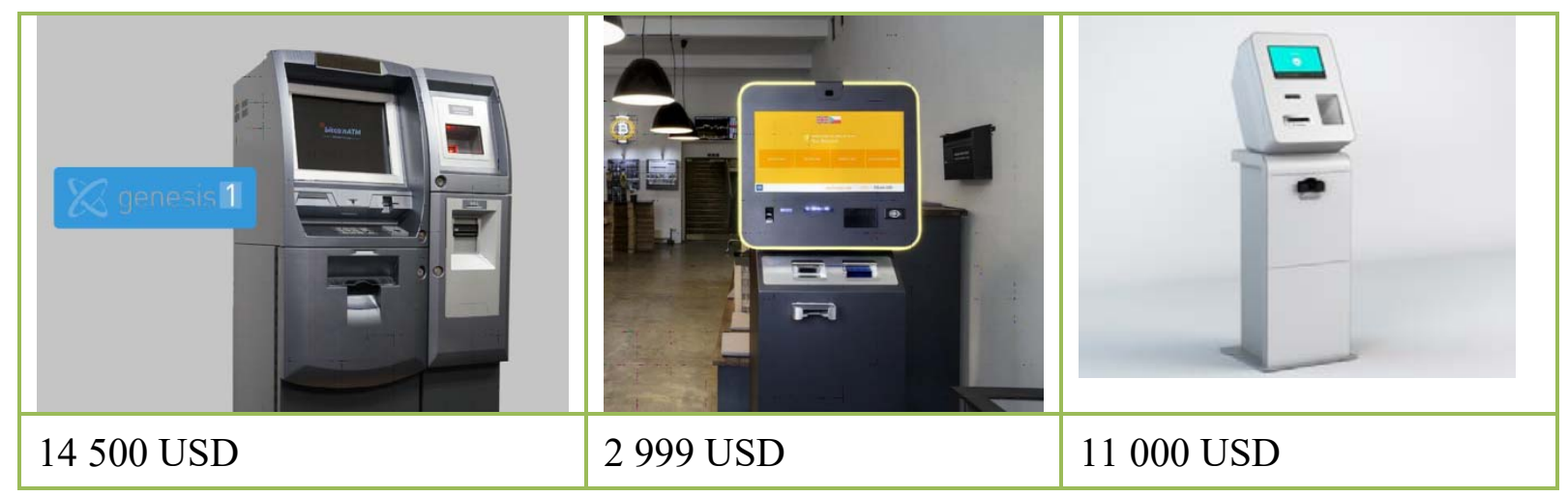

Zdroj: Vlastné spracovanie

Nasleduje výber niekol'kých zistení z dotazníka. Jedna z otázok bola: „Nachádza sa vo Vašom meste bankomat na virtuálnu menu?"

Touto otázkou sme chceli zistit’ či sa nachádza v okolí respondenta bankomat na virtuálnu menu. Zo 294 opýtaných odpovedalo najviac 162 (55\%), že sa v ich okolí nenachádza bankomat na virtuálnu menu, 108 (37\%) respondentov nevie, či sa v ich okolí nachádza bankomat na virtuálnu menu. A iba $24(8 \%)$ respondentov odpovedalo, že sa nachádza $\mathrm{v}$ ich okolí bankomat na virtuálnu menu. Výskumný predpoklad bol: Polovica opýtaných respondentov nevie či sa bankomat na virtuálnu menu nachádza $\mathrm{v}$ ich okolí. Tento predpoklad sa nepotvrdil. Väčšina opýtaných (55\%), odpovedalo že sa v ich okolí nenachádza bankomat na virtuálnu menu (vid' obrázok 4).

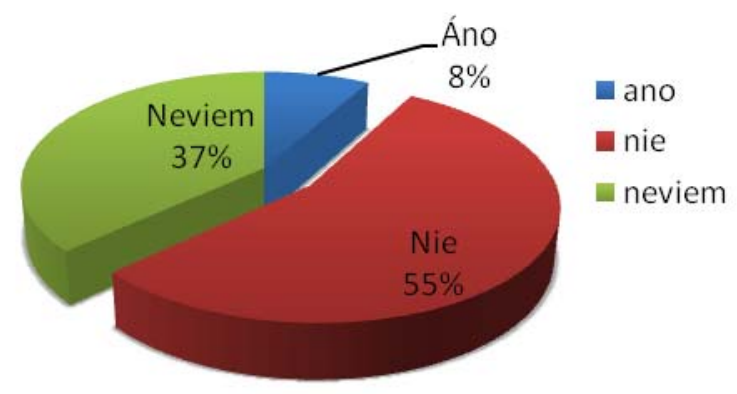

\section{Obrázok 4 Grafické znázornenie bankomatu v okolí (Vlastné spracovanie)}

$\mathrm{Na}$ otázku (obrázok č. 5), či by uvítali bankomaty na virtuálnu menu na poštách, väčšina z 294 opýtaných respondentov odpovedala, že nevedia 96 (33\%). Naopak túto možnost' by privítalo 60 (21\%) opýtaných. Skôr áno 54 (18\%), skôr nie $42(14 \%)$ a nie 42 (14\%). Výskumný predpoklad: Bankomaty na virtuálnu menu by $\mathrm{v}$ poštovom podniku privítala polovica respondentov. Tento predpoklad sa potvrdil, záujem o bankomat na virtuálnu menu má väčšina respondentov.

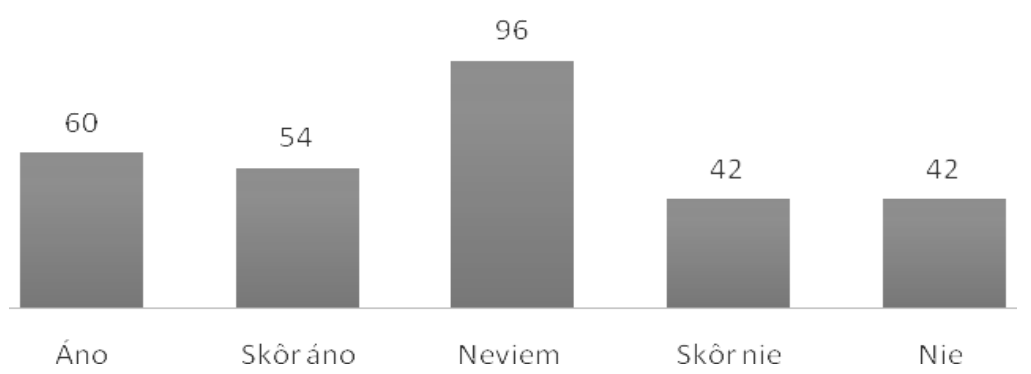

Obrázok 5 Záujem o bankomat v poštovom podniku (Vlastné spracovanie) 
Ďalšia otázka znela (obrázok č. 6): „Využili by ste možnost' platit' virtuálnou menou poštové služby?" Táto otázka úzko súvisí s predchádzajúcou a tomu značia odpovede, že väššina z opýtaných 294 respondentov by nevedela, či túto službu využije 78 respondentov (26\%), nie označilo $77(26 \%)$, skôr nie 53 (18\%), áno odpovedalo $34(12 \%)$ a skôr áno 52 (18\%) opýtaných respondentov. Výskumný predpoklad: „Polovica respondentov by využila možnost' platit' digitálnou menou v poštovom podniku.“ Je možné považovat' za nepravdivý, väčšina respondentov odpovedalo, že nevie či by túto službu využili.

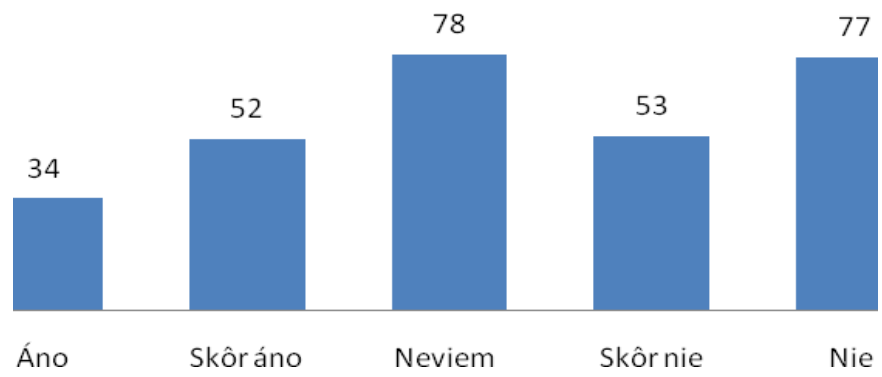

Obrázok 6 Záujem o platbu poštových služieb (Vlastné spracovanie)

Druhý dotazník skúmal poštové podniky. Na otázku či ponúkajú možnost' platit' virtuálnou menou všetky oslovené poštové podniky odpovedali rovnako, že neponúkajú túto službu. Výskumný predpoklad: Žiadny poštový podnik neponúka možnost' platit' digitálnou menou. Tento predpoklad sa potvrdil, na území Slovenskej republiky neponúka žiadny poštový podnik túto službu.

Pýtali sme sa aj: Plánujete do budúcna ponúknut' možnost' platit' digitálnou menou vo Vašom poštovom podniku? Otázka bola zameraná na to, či plánujú ponúknut' možnost' platit' digitálnou menou v poštovom podniku. Najviac podnikov $13(68 \%)$ odpovedalo nie, zvyšných 6 podnikov nevie odpovedat'. Výskumný predpoklad: V žiadnom poštovom podniku neplánujú zaviest' možnost' platit' virtuálnou menou. Tento predpoklad sa tak isto potvrdil ako pravdivý, žiadny poštový podnik neplánuje zaviest' platby digitálnou menou (pozri obrázok 7).

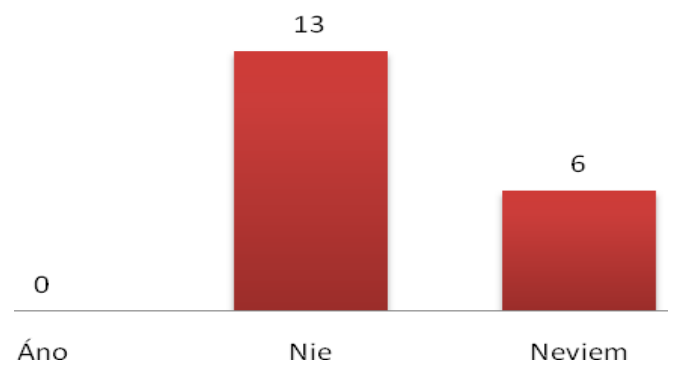

Obrázok 7 Plán poštových podnikov zaviest' možnost' platby digitálnou menou na pobočkách

Z d’alšieho výskumu vyplynulo, že v prípade záujmu zo strany zákazníkov o platbu digitálnou menou, by 4 poštové podniky mali záujem prevádzkovat' bankomaty. Ak by bol reálny záujem o túto službu 4 (21\%) podniky si vedia predstavit', že by túto službu ponúkali. Odpovedat' nevedelo 11 (58\%) podnikov, a odpoved' nie označili 4 (21\%) podnikov.

\section{Záver}

Silnou konkurenciou sú podniky nútené svoje portfólio neustále rozširovat' a digitalizovat' aby sa udržali na trhu. $\mathrm{Na}$ našom trhu služba nákupu digitálnych mien prostredníctvom bankomatov na virtuálne meny $\mathrm{v}$ poštovom podniku síce ešte chýba, no týmto trendom sa časom prispôsobia. Bankomaty na virtuálnu menu na Slovensku ktoré máme nie sú prevádzkovane poštovými podnikmi. 
V súčasnosti je Európa relatívne malým burzovým trhom s virtuálnymi menami. V porovnaní s inými významnými trhmi, ako sú USA, Japonsko a Č́na, Bitcoin bankomaty Európe chýbajú. Iné štáty, ako napr. Južná Kórea , prešli k ATM nákupom vd’aka nízkym prevádzkovým a výrobným nákladom. Aplikácie založené na mene Bitcoin začali spolupracovat' s bankami a poskytovatel'mi služieb ATM, aby umožnili nákupy Bitcoin na existujúcich bankomatoch.

Pomocou dotazníka č. 2, sme urobili prieskum o reálnom záujme zákazníkov poštových podnikov. Z uvedených odpovedí vyplýva, že ani jeden túto službu neponúka. Dopyt o službu poštové podniky nezaznamenali v takej miere aby začali uvažovat' o zavedení takýchto automatov, alebo samotného predaja virtuálnej meny. No vedia si predstavit' v prípade reálneho záujmu zo strany zákazníkov, ponúkat’ túto službu.

\section{Literatúra}

[1] Mecková, Z.: Bitcoin: Koniec peňazí, ako ich poznáme. Dokument odhal'uje budúcnost', o akej zatial' len snívame. Financial Report. 2020. [Cit. 9.10.2021]. Dostupné online na: https:/www.finreport.sk/volny-cas/bitcoin-koniec-penazi-ako-ich-pozname-dokumentodhaluje-buducnost-o-akej-zatial-len-snivame/

[2] Fabuš, J., Kremeňova, I.: The survey of using ICT for international cooperation administration in education. pp. 144-148.

[3] Register poštových podnikov, 2021. Dostupné online na: https://www.teleoff.gov.sk/zoznam-podnikov/

[4] Fabuš, J., Kremeňová, I.: Evolution of Post in region of Žilina. International Journal of Science and Engineering Applications, 2(2), str. 34-35. 2013.

[5] Slovník pojmov. [Cit. 9.10. 2021]. Dostupné online na: <http://banky.sk/bankomat-atmautomated-teller-machine/>.

[6] Greelane: Prečo bol vynález ATM tímovým úsilím. 2019. [Cit. 9.10. 2021]. Dostupné online na: https://www.greelane.com/sk/humanities $/$ hist $\%$ c3\%b3ria-akult\%c3\%bara/automatic-teller-machines-atm-1991236/

[7] Fekete, D.: Čo je to vlastne kryptomena a prečo sa do nej oplatí investovat? Tu je základný sprievodca pre začiatočníkov. Hashtag Zoznam, 2020. [Cit. 9.10. 2021]. Dostupné online na: https://hashtag.zoznam.sk/kryptomena-zakladny-sprievodca-prezaciatocnikov/

[8] EBA: EBA warns consumers on virtual currencies. 2013. [Cit. 9.10. 2021]. Dostupné online na: https://www.eba.europa.eu/eba-warns-consumers-on-virtual-currencies

[9] ESMA, EBA and EIOPA warn consumers on the risks of Virtual Currencies. [Cit. 9.10. 2021]. Dostupné online na: https://www.iosco.org/library/ico-statements/Europe\%20$\% 20$ ESA $\% 20$ -

$\%$ 20ESMA, $\% 20$ EBA $\% 20$ and $\% 20$ EIOPA $\% 20$ warn $\% 20$ consumers $\% 20$ on $\% 20$ the $\% 20$ risk s\%20of\%20Virtual\%20Currencies.pdf

[10]V pražských Holešovicích funguje bankomat na bitcoiny. První v Česku. iRozhlas, 2014. [Cit. 10.10. 2021]. Dostupné online na: https://www.irozhlas.cz/node/5915425/

[11]Za Bitcoiny je možné platit na poštách a terminálech Sazky. Denik, 2015. [Cit. 10.10. 2021]. Dostupné online na: https://www.denik.cz/ekonomika/za-bitcoiny-je-mozne-platitna-postach-a-terminalech-sazky-20150121.html

[12] Slížek, D.: Za bitcoiny už je možné platit i na poště nebo přes terminál Sazky. Lupa, 2015. [Cit. 10.10. 2021]. Dostupné online na: https://www.lupa.cz/clanky/za-bitcoiny-uzje-mozne-platit-i-na-poste-nebo-pres-terminal-sazky/

[13] Coin ATM radar: Bitcoin ATMs in Austria. 2021. [Cit. 10.10. 2021]. Dostupné online na: https://coinatmradar.com/country/14/bitcoin-atm-austria/ 
[14]Coin ATM radar: Bitcoin ATMs by Country. 2021. [Cit. 10.10. 2021]. Dostupné online na: https://coinatmradar.com/countries/

[15]Coleman, L.: Austrian Post Offices Sell Bitcoin, Ethereum and More For Cash. 2017. [Cit. 10.10. 2021]. Dostupné online na: https://www.ccn.com/post-offices-in-austria-sellcryptocurrencies-for-cash/

[16]Buy Bitcoin In Austria At 1800 Post Offices With Bitpanda. 2017. [Cit. 10.10. 2021]. Dostupné online na: https://cryptocoindaddy.com/buy-bitcoin-in-austria-at-1800-postoffices-with-bitpanda/

[17]Coin ATM radar. 2018. [Cit. 10.10. 2021]. Dostupné online na: https://coinatmradar.com/

[18]Česko má prvý automat na bitcoiny, ktorý umožňuje vybrat' hotovost'. TASR, 2014. [Cit. 10.10. 2021]. Dostupné online na: https://www.teraz.sk/ekonomika/cesko-bitcoinautomat/85926-clanok.html?mostViewedArticlesInSectionTab $=0$

\section{Grantová podpora}

The Paper is published with the support of project VEGA 1/0518/19. This research has been further supported by the University of Zilina in the scope of Institutional research $1 / \mathrm{KS} / 2020$, by Project K-21-015-00 and Project CIS by Ministry of Educations SR. 